Review

\title{
Current status of endovascular treatment for dural arteriovenous fistulae in the anterior cranial fossa: $A$ systematic literature review
}

\author{
Kan $\mathrm{Xu}^{1^{*}}$, Tiefeng $\mathrm{Ji}^{2^{*}}$, Chao $\mathrm{Li}^{3}$, Jinlu $\mathrm{Yu}^{1 凶}$ \\ 1. Department of Neurosurgery, The First Hospital of Jilin University, Changchun, 130021, China \\ 2. Department of Radiology, The First Hospital of Jilin University, Changchun, 130021, China \\ 3. Department of Neurology, The First Hospital of Jilin University, Changchun, 130021, China \\ *These authors contributed equally to this work. \\ $\square$ Corresponding author: Department of Neurosurgery, The First Hospital of Jilin University, 71 Xinmin Avenue, Changchun 130021, China \\ (c) Ivyspring International Publisher. This is an open access article distributed under the terms of the Creative Commons Attribution (CC BY-NC) license \\ (https://creativecommons.org/licenses/by-nc/4.0/). See http://ivyspring.com/terms for full terms and conditions.
}

Received: 2018.09.01; Accepted: 2018.12.04; Published: 2019.01.01

\begin{abstract}
Anterior cranial fossa (ACF) dural arteriovenous fistulae (DAVFs) are rare, and a systematic review of the literature is lacking. Such a review is necessary, however, so a systematic PubMed search of related studies was performed. Twenty-four studies were identified, reporting on 48 patients, of whom 39 had definite age and sex information and 33 (84.6\%, 33/39) were male. The afflicted patients were between 37 and 80 years old (mean 55.6). Among the 48 patients, 28 (58.3\%, 28/48) primarily presented with intracranial hemorrhage, $47(97.9 \%, 47 / 48)$ had feeding arteries from the anterior ethmoidal artery (AEA) of the ophthalmic artery (OA), and $40(83.3 \%, 40 / 48)$ had bilateral feeding arteries. All of the cases had high-grade Cognard classifications (III-IV). Among the 48 patients, $43(89.6 \%, 43 / 48)$ had drainage into the superior sagittal sinus (SSS). In addition, $36(75 \%, 36 / 48)$ patients were treated via transarterial embolization (TAE). Of these patients, $28(77.8 \%, 28 / 36)$ were managed via the AEA of the OA. Another $12(25 \%, 12 / 48)$ patients were treated via transvenous embolization (TVE), 11 of whom $(91.7 \%, 11 / 12)$ were treated with the trans-SSS approach. Complete angiographic cure was achieved in $44(91.7 \%, 44 / 48)$ patients, with $4(8.3 \%, 4 / 48)$ patients suffering from postprocedural complications. All 48 patients had clear descriptions of follow-up outcomes, with $45(93.8 \%, 45 / 48)$ patients having a good outcome. Thus, when treating ACF DAVFs, endovascular treatment (EVT) can completely obliterate the fistula point and correct the venous shunting. EVT is therefore an effective treatment for ACF DAVF. Although many complications can occur, this approach achieves good outcomes in most cases.
\end{abstract}

Key words: endovascular treatment, dural arteriovenous fistula, anterior cranial fossa, systematic review

\section{Introduction}

A dural arteriovenous fistula (DAVF) is an arteriovenous shunt located in the dural wall of the venous sinus or the expanded layer of the dura mater [1-3]. Intracranial DAVFs account for only $10 \%$ to $15 \%$ of intracranial vascular malformations, and only $10 \%$ of all DAVFs are located in the anterior cranial fossa (ACF) [4-7]. Therefore, the rate of ACF DAVFs is $1 \%$ to $1.5 \%$ of intracranial vascular malformations, which is very rare.

ACF DAVFs are also termed ethmoidal DAVFs or cribriform plate DAVFs. These vascular events are notorious for their proclivity to drain directly into cortical veins, indicating a malignant natural history and a high bleeding risk in $91 \%$ of cases. Hence, ACF DAVFs are usually treated regardless of whether they are symptomatic $[4,8]$.

Currently, treatments for ACF DAVFs include surgical resection, endovascular treatment (EVT) and stereotactic radiosurgery [9]. Surgical resection is very effective because it has low postoperative morbidity and can achieve a complete cure [8, 10]. However, surgical resection is also associated with risks inherent to frontal craniotomy, including fontal sinus opening, cerebrospinal fluid leakage, intradural 
infection, and retraction damage to the frontal lobe and olfactory nerves [11]. Radiosurgery has been described as an efficient treatment, but an extended period of time is required to occlude the DAVF [9].

Recently, trends in the management of ACF DAVF have been significantly affected by technological advances in EVT related to the widespread use of new microcatheters, and morbidity and modality have apparently been reduced [8]. Since its introduction in 2000, the Onyx Liquid Embolic System (Irvine, CA, USA) has been widely used for embolization in DAVFs and is easier to control than previously available liquid agents [12, 13]. EVT, including transarterial embolization (TAE) and transvenous embolization (TVE), is currently considered the first therapeutic option for ACF DAVFs $[14,15]$.

Current data regarding EVT for ACF DAVFs are sporadic. No systematic review of EVT for ACF DAVFs has previously been published; hence, we reviewed the available literature on this subject. Literature searches identified 48 cases of EVT for ACF DAVFs, which are shown in Table 1. Meanwhile, general and angiographic data on the ACF DAVF series are summarized in Table 2. In this article, EVT for ACF DAVFs is the primary focus of the systematic literature review.

\section{Material and methods}

This systematic review was conducted in accordance with the Preferred Reporting Items for Systematic Reviews and Meta-Analyses (PRISMA) guidelines [16]. Eligible English language articles (case reports, case series, and studies considering ACF DAVFs treated via EVT) were identified through searches of PubMed published (last search date was October 2018).

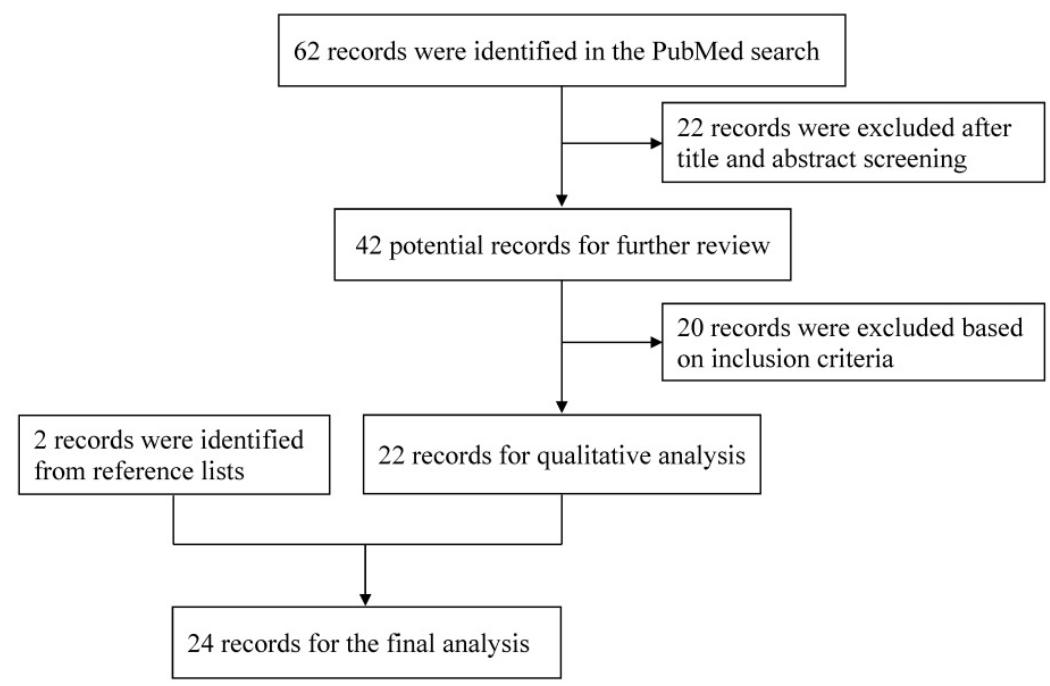

Figure 1. Flow chart of the search strategies.
The search algorithm used the terms "anterior cranial fossa dural arteriovenous fistula," "cribriform plate arteriovenous fistula," "ethmoidal dural arteriovenous fistula" and "embolization" as key words in relevant combinations. The reference lists of the identified articles were also manually searched for additional studies. The resulting flowchart is depicted in Figure 1.

The inclusion criteria were as follows: a) full text was available, b) clinical data were largely complete, and c) EVT was the only treatment used. Patients from EVT studies without sufficient descriptions of the individual demographic, clinical, and radiological data were excluded.

\section{Results}

\section{General demographic, clinical, and radiological characteristics}

Twenty-four studies [9, 11, 12, 14, 17-36] were identified in the literature search, reporting on a total of 48 patients who met the inclusion criteria. Of these patients, 39 had definite age and sex information, 33 $(84.6 \%, 33 / 39)$ were male, and $6(15.4 \%, 6 / 39)$ were female. The affected patients ranged in age from 37 to 80 years (mean 55.6). Of these 48 patients, 28 (58.3\%, $28 / 48$ ) primarily presented with intracranial hemorrhage (including intracerebral hematoma, subarachnoid hemorrhage, subdural hematoma and intraventricular hemorrhage).

Among the 48 patients, $47(97.9 \%, 47 / 48)$ had feeding arteries from the anterior ethmoidal artery (AEA) of the ophthalmic artery (OA), 10 (20.8\%, $10 / 48$ ) patients had feeding arteries from the middle meningeal artery (MMA), $16(33.3 \%, 16 / 48)$ patients had feeding arteries from the ethmoidal branches of internal maxillary artery (IMA), and one $(2.1 \%, 1 / 48)$ had feeding arteries from the posterior ethmoidal artery (PEA) of the OA. Among the 48 patients, $40(83.3 \%, 40 / 48)$ had bilateral feeding arteries, with the remaining $8 \quad(16.7 \%, 8 / 48)$ having unilateral feeding arteries. All 48 cases were high-grade according to the Cognard classification (III-IV) system. Of the 48 patients, $43(89.6 \%, 43 / 48)$ had drainage into the superior sagittal sinus (SSS), and $8(16.7 \%, 8 / 48)$ patients had drainage via the Basal vein of Rosenthal.

\section{Treatment process}

Of the 48 patients, $36(75 \%, 36 / 48)$ were treated via TAE. Of these 36 patients, $28(77.8 \%, 28 / 36)$ were managed via the AEA of the OA, and $6(16.7 \%$, 
6/36) were managed via the middle meningeal artery (MMA).

Of the 48 patients, $12(25 \%, 12 / 48)$ patients were treated via TVE, and $11(91.7 \%, 11 / 12)$ were treated via the trans-SSS approach. Of the 12 patients treated via TVE, $2(16.7 \%, 2 / 12)$ had previously undergone TAE.

\section{Outcome and follow-up}

Of the 48 patients, all treated via TAE, complete angiographic cure was achieved in $44(91.7 \%, 44 / 48)$, while $4(8.3 \%, 4 / 48)$ patients experienced incomplete angiographic cure. Four $(8.3 \%, 4 / 48)$ patients suffered complications, of whom $1(2.1 \%, 1 / 48)$ exhibited edema of the thalamus and midbrain, $2(4.2 \%, 2 / 47)$ exhibited excessive Onyx reflux, and $1(2.1 \%, 1 / 48)$ experienced microcatheter retention. The clinical data are summarized in Table 1. All 48 patients had definite descriptions of follow-up outcomes. In total, $45(93.8 \%, 45 / 48)$ patients had good outcomes, 2 $(4.2 \%, 2 / 48)$ had improved neurological state, and 1 $(2.1 \%, 1 / 48)$ was worse than before operation.

Table 1: Clinical data for patients with EVT for ACF DAVF

\begin{tabular}{|c|c|c|c|c|c|c|c|c|c|c|}
\hline No. & Author/Year & Age/Sex & Presentation & Feeding arteries & Venous drainage & $\begin{array}{l}\text { Cognard } \\
\text { type }\end{array}$ & EVT & $\begin{array}{l}\text { Angiographic } \\
\text { cure }\end{array}$ & Complication & Outcome \\
\hline 1 & $\begin{array}{l}\text { Matsumaru et } \\
\text { al./1997[17] }\end{array}$ & $62 / \mathrm{M}$ & $\mathrm{IH}$ & $\begin{array}{l}\text { Bilateral AEA of the } \\
\text { OA }\end{array}$ & $\begin{array}{l}\text { Frontal vein to the } \\
\text { SSS }\end{array}$ & III & $\begin{array}{l}\text { TAE: via both AEAs } \\
\text { of the OAs with } \\
\text { NBCA }\end{array}$ & Complete & No & Good \\
\hline 2 & $\begin{array}{l}\text { Defreyne et } \\
\text { al./2000[11] }\end{array}$ & $40 / \mathrm{M}$ & SAH & $\begin{array}{l}\text { Bilateral AEA of the } \\
\text { OA; Ethmoidal } \\
\text { branches of the IMA }\end{array}$ & $\begin{array}{l}\text { Frontal vein to the } \\
\text { SSS }\end{array}$ & III & $\begin{array}{l}\text { TVE: trans-SSS } \\
\text { approach with coils. }\end{array}$ & Complete & No & Good \\
\hline 3 & $\begin{array}{l}\text { Defreyne et } \\
\text { al./2000[11] }\end{array}$ & $39 / \mathrm{M}$ & Asymptomatic & $\begin{array}{l}\text { Bilateral AEA of the } \\
\text { OA }\end{array}$ & $\begin{array}{l}\text { Frontal vein to the } \\
\text { SSS; Basal vein of } \\
\text { Rosenthal }\end{array}$ & IV & $\begin{array}{l}\text { TVE: trans-SSS } \\
\text { approach with coils. }\end{array}$ & Complete & No & Good \\
\hline 4 & $\begin{array}{l}\text { Abrahams et } \\
\text { al./2002[18] }\end{array}$ & $77 / \mathrm{M}$ & Dementia & $\begin{array}{l}\text { Bilateral AEA of the } \\
\text { OA; Ethmoidal } \\
\text { branches of the IMA } \\
\text { and MMA }\end{array}$ & $\begin{array}{l}\text { Frontal vein to the } \\
\text { SSS }\end{array}$ & IV & $\begin{array}{l}\text { TAE: via ethmoidal } \\
\text { branches of the IMA } \\
\text { or MMA }\end{array}$ & Incomplete & No & Good \\
\hline 5 & $\begin{array}{l}\text { Flynn et } \\
\text { al./2007[19] }\end{array}$ & $39 / F$ & $\mathrm{IH}$ & $\begin{array}{l}\text { Unilateral AEA of the } \\
\text { OA }\end{array}$ & $\begin{array}{l}\text { Basal vein of } \\
\text { Rosenthal }\end{array}$ & IV & $\begin{array}{l}\text { TAE: via the AEA of } \\
\text { the OA with NBCA }\end{array}$ & Complete & No & Good \\
\hline 6 & $\begin{array}{l}\text { Lv et } \\
\text { al./2007[20] }\end{array}$ & $52 / \mathrm{M}$ & $\mathrm{IH}$ & $\begin{array}{l}\text { Bilateral AEA of the } \\
\text { OA and ethmoidal } \\
\text { branches of the IMA }\end{array}$ & $\begin{array}{l}\text { Frontal vein to the } \\
\text { SSS }\end{array}$ & IV & $\begin{array}{l}\text { TAE: via both AEAs } \\
\text { of the OA with Onyx, } \\
\text { two stages. }\end{array}$ & Complete & No & Good \\
\hline 7 & $\begin{array}{l}\text { Katsaridis et } \\
\text { al./2007[21] }\end{array}$ & $76 / \mathrm{M}$ & $\mathrm{IH}$ & $\begin{array}{l}\text { Bilateral AEAs of the } \\
\text { OAs }\end{array}$ & $\begin{array}{l}\text { Frontal vein to the } \\
\text { SSS }\end{array}$ & IV & $\begin{array}{l}\text { TAE: via both AEAs } \\
\text { of the OAs with } \\
\text { NBCA }\end{array}$ & Complete & No & Good \\
\hline 8 & $\begin{array}{l}\text { Lv et } \\
\text { al./2008[22] }\end{array}$ & $65 / \mathrm{M}$ & $\begin{array}{l}\text { Dementia and } \\
\text { seizure }\end{array}$ & $\begin{array}{l}\text { Unilateral AEA of the } \\
\text { OA and ethmoidal } \\
\text { branches of the IMA }\end{array}$ & $\begin{array}{l}\text { Frontal vein to the } \\
\text { SSS }\end{array}$ & III & $\begin{array}{l}\text { TAE: via the AEA of } \\
\text { the OA with Onyx. } \\
\text { TVE: trans-SSS } \\
\text { approach with coils. }\end{array}$ & Complete & No & Good \\
\hline 9 & $\begin{array}{l}\text { Lv et } \\
\text { al./2008[23] }\end{array}$ & $48 / \mathrm{M}$ & $\begin{array}{l}\text { Headache and } \\
\text { blurred vision }\end{array}$ & $\begin{array}{l}\text { Bilateral AEA of the } \\
\text { OA, ethmoidal } \\
\text { branches of the IMA } \\
\text { and MMA }\end{array}$ & $\begin{array}{l}\text { Frontal vein to the } \\
\text { SSS }\end{array}$ & III & $\begin{array}{l}\text { TVE: trans-SSS } \\
\text { approach with coils. }\end{array}$ & Complete & No & Good \\
\hline 10 & $\begin{array}{l}\text { Lv et } \\
\text { al./2008[23] }\end{array}$ & $60 / \mathrm{M}$ & $\mathrm{IH}$ & $\begin{array}{l}\text { Bilateral AEAs of the } \\
\text { OAs }\end{array}$ & $\begin{array}{l}\text { Frontal vein to } \\
\text { cavernous sinus }\end{array}$ & IV & $\begin{array}{l}\text { TAE: via the AEA of } \\
\text { the OA with Onyx }\end{array}$ & Complete & No & Good \\
\hline 11 & $\begin{array}{l}\text { Tahon et } \\
\text { al./2008[24] }\end{array}$ & $50 / \mathrm{M}$ & Headache & $\begin{array}{l}\text { Bilateral AEA of the } \\
\text { OA and MMA, both } \\
\text { pial branches of the } \\
\text { ACA and MCA }\end{array}$ & $\begin{array}{l}\text { Frontal vein to the } \\
\text { SSS; Basal vein of } \\
\text { Rosenthal }\end{array}$ & IV & $\begin{array}{l}\text { TAE: via the MMA } \\
\text { with Onyx }\end{array}$ & Complete & No & Good \\
\hline 12 & $\begin{array}{l}\text { Tsutsumi et } \\
\text { al./2009[25] }\end{array}$ & $59 / \mathrm{M}$ & $\mathrm{IH}$ & $\begin{array}{l}\text { Bilateral AEA of the } \\
\text { OA; Unilateral } \\
\text { persistent primitive } \\
\text { olfactory artery }\end{array}$ & $\begin{array}{l}\text { Frontal vein to the } \\
\text { SSS }\end{array}$ & III & $\begin{array}{l}\text { TAE: via persistent } \\
\text { primitive olfactory } \\
\text { artery and AEA of } \\
\text { the OA with NBCA }\end{array}$ & Incomplete & No & Good \\
\hline 13 & $\begin{array}{l}\text { Agid et } \\
\text { al./2009[9] }\end{array}$ & $55 / \mathrm{M}$ & $\mathrm{IH}$ & $\begin{array}{l}\text { Bilateral AEA of the } \\
\text { OA; Ethmoidal } \\
\text { branches of the IMA }\end{array}$ & $\begin{array}{l}\text { Frontal vein to the } \\
\text { SSS }\end{array}$ & IV & $\begin{array}{l}\text { TAE: via the AEA of } \\
\text { the OA with NBCA }\end{array}$ & Complete & No & Good \\
\hline 14 & $\begin{array}{l}\text { Guedin et } \\
\text { al./2010[26] }\end{array}$ & $75 / \mathrm{M}$ & $\mathrm{IH}$ & $\begin{array}{l}\text { Unilateral the PEA of } \\
\text { the OA }\end{array}$ & $\begin{array}{l}\text { Frontal vein to the } \\
\text { SSS }\end{array}$ & IV & $\begin{array}{l}\text { TAE: via the PEA of } \\
\text { the OA with Onyx }\end{array}$ & Complete & No & Good \\
\hline 15 & $\begin{array}{l}\text { Ishihara et } \\
\text { al./2010[27] }\end{array}$ & $71 / \mathrm{M}$ & Blurred vision & $\begin{array}{l}\text { Bilateral facial } \\
\text { arteries; Unilateral } \\
\text { AEA of the OA }\end{array}$ & $\begin{array}{l}\text { Frontal vein to the } \\
\text { SSS }\end{array}$ & III & $\begin{array}{l}\text { TAE: via facial artery } \\
\text { with NBCA }\end{array}$ & Complete & No & Good \\
\hline 16 & $\begin{array}{l}\text { Mack et } \\
\text { al./2011[28] }\end{array}$ & $57 / \mathrm{M}$ & $\mathrm{SAH}$ & $\begin{array}{l}\text { Bilateral AEA of the } \\
\text { OA and ethmoidal } \\
\text { branches of the IMA }\end{array}$ & $\begin{array}{l}\text { Frontal vein to the } \\
\text { SSS }\end{array}$ & IV & $\begin{array}{l}\text { TAE: via the AEA of } \\
\text { the OA with Onyx }\end{array}$ & Complete & No & Good \\
\hline 17 & $\begin{array}{l}\text { Mack et } \\
\text { al./2011[28] }\end{array}$ & $54 / \mathrm{F}$ & $\begin{array}{l}\text { Headache and } \\
\text { vision } \\
\text { impairment }\end{array}$ & $\begin{array}{l}\text { Bilateral AEA and the } \\
\text { PEA of the OA }\end{array}$ & $\begin{array}{l}\text { Basal vein of } \\
\text { Rosenthal }\end{array}$ & IV & $\begin{array}{l}\text { TAE: via both AEAs } \\
\text { of the OA with } \\
\text { NBCA and Onyx }\end{array}$ & Complete & $\begin{array}{l}\text { Edema of } \\
\text { thalamus/ } \\
\text { midbrain }\end{array}$ & IM \\
\hline 18 & $\begin{array}{l}\text { Zhao et } \\
\text { al./2012[29] }\end{array}$ & $58 / \mathrm{M}$ & $\mathrm{SDH}$ & $\begin{array}{l}\text { Unilateral AEA of the } \\
\text { OA }\end{array}$ & $\begin{array}{l}\text { Frontal vein to the } \\
\text { SSS }\end{array}$ & IV & $\begin{array}{l}\text { TAE: via the AEA of } \\
\text { the OA with Onyx. }\end{array}$ & Complete & No & Good \\
\hline 19 & $\begin{array}{l}\text { Li et } \\
\text { al./2013[12] }\end{array}$ & $37 / \mathrm{M}$ & SAH & $\begin{array}{l}\text { Bilateral AEA of the } \\
\text { OA; Branch of the }\end{array}$ & $\begin{array}{l}\text { Frontal vein to the } \\
\text { SSS }\end{array}$ & IV & $\begin{array}{l}\text { TAE: via the AEA of } \\
\text { the OA and branch of }\end{array}$ & Incomplete & Excessive reflux & Good \\
\hline
\end{tabular}




\begin{tabular}{|c|c|c|c|c|c|c|c|c|c|c|}
\hline & & & & facial artery; MMA & & & $\begin{array}{l}\text { the facial artery with } \\
\text { Onyx, twice stages. }\end{array}$ & & & \\
\hline 20 & $\begin{array}{l}\text { Li et } \\
\text { al./2013[12] }\end{array}$ & $52 / \mathrm{M}$ & Blurred vision & $\begin{array}{l}\text { Bilateral AEA of the } \\
\text { OA; Pial branch of the } \\
\text { ACA }\end{array}$ & $\begin{array}{l}\text { Frontal vein to the } \\
\text { SSS }\end{array}$ & III & $\begin{array}{l}\text { TAE: via AEA of the } \\
\text { OA with Onyx. }\end{array}$ & Complete & No & Good \\
\hline 21 & $\begin{array}{l}\text { Li et } \\
\text { al./2013[12] }\end{array}$ & $68 / \mathrm{M}$ & IH, IVH & $\begin{array}{l}\text { Bilateral AEA of the } \\
\text { OA; Ethmoidal } \\
\text { branches of the IMA }\end{array}$ & $\begin{array}{l}\text { Frontal vein to the } \\
\text { SSS }\end{array}$ & IV & $\begin{array}{l}\text { TAE: via the AEA of } \\
\text { the OA with Onyx. }\end{array}$ & Complete & No & Worse \\
\hline 22 & $\begin{array}{l}\text { Li et } \\
\text { al./2013[12] }\end{array}$ & $60 / \mathrm{M}$ & $\mathrm{IH}, \mathrm{SDH}$ & $\begin{array}{l}\text { Bilateral AEA of the } \\
\text { OA; Ethmoidal } \\
\text { branches of the IMA }\end{array}$ & $\begin{array}{l}\text { Frontal vein to the } \\
\text { SSS }\end{array}$ & IV & $\begin{array}{l}\text { TAE: via the AEA of } \\
\text { the OA with Onyx. }\end{array}$ & Complete & No & Good \\
\hline 23 & $\begin{array}{l}\text { Li et } \\
\text { al./2013[12] }\end{array}$ & $54 / \mathrm{M}$ & $\mathrm{SAH}$ & $\begin{array}{l}\text { Bilateral AEA of the } \\
\text { OA; Pial branch of the } \\
\text { ACA }\end{array}$ & $\begin{array}{l}\text { Frontal vein to the } \\
\text { SSS }\end{array}$ & IV & $\begin{array}{l}\text { TAE: via the AEA of } \\
\text { the OA with Onyx. }\end{array}$ & Complete & No & Good \\
\hline 24 & $\begin{array}{l}\text { Li et } \\
\text { al./2013[12] }\end{array}$ & $43 / \mathrm{M}$ & $\mathrm{IH}, \mathrm{IVH}$ & $\begin{array}{l}\text { Bilateral AEA of the } \\
\text { OA; MMA }\end{array}$ & $\begin{array}{l}\text { Frontal vein to the } \\
\text { SSS }\end{array}$ & IV & $\begin{array}{l}\text { TAE: via AEA of the } \\
\text { OA with Onyx. }\end{array}$ & Complete & No & Good \\
\hline 25 & $\begin{array}{l}\text { Li et } \\
\text { al./2013[12] }\end{array}$ & $55 / \mathrm{M}$ & IH, IVH & $\begin{array}{l}\text { Bilateral AEA of the } \\
\text { OA }\end{array}$ & $\begin{array}{l}\text { Frontal vein to the } \\
\text { SSS }\end{array}$ & III & $\begin{array}{l}\text { TAE: via the AEA of } \\
\text { the OA with Onyx. }\end{array}$ & Complete & Excessive reflux & Good \\
\hline 26 & $\begin{array}{l}\text { Li et } \\
\text { al./2013[12] }\end{array}$ & $57 / F$ & $\mathrm{SAH}$ & $\begin{array}{l}\text { Bilateral AEA of the } \\
\text { OA; Ethmoidal } \\
\text { branches of the IMA }\end{array}$ & $\begin{array}{l}\text { Frontal vein to the } \\
\text { SSS }\end{array}$ & IV & $\begin{array}{l}\text { TAE: via the AEA of } \\
\text { the OA with Onyx. }\end{array}$ & Complete & No & Good \\
\hline 27 & $\begin{array}{l}\text { Li et } \\
\text { al./2013[12] }\end{array}$ & $40 / \mathrm{M}$ & Headache & $\begin{array}{l}\text { Bilateral AEA of the } \\
\text { OA; Branches of the } \\
\text { facial artery }\end{array}$ & $\begin{array}{l}\text { Frontal vein to the } \\
\text { SSS }\end{array}$ & IV & $\begin{array}{l}\text { TAE: via AEA of the } \\
\text { OA with Onyx. }\end{array}$ & Complete & No & Good \\
\hline 28 & $\begin{array}{l}\text { Li et } \\
\text { al./2013[12] }\end{array}$ & $37 / \mathrm{M}$ & $\mathrm{IH}, \mathrm{SDH}$ & $\begin{array}{l}\text { Bilateral AEA of the } \\
\text { OA; Branches of the } \\
\text { facial artery; MMA }\end{array}$ & $\begin{array}{l}\text { Frontal vein to the } \\
\text { SSS }\end{array}$ & III & $\begin{array}{l}\text { TAE: via the AEA of } \\
\text { the OA with Onyx. }\end{array}$ & Complete & No & Good \\
\hline 29 & $\begin{array}{l}\text { Li et } \\
\text { al./2013[12] }\end{array}$ & $42 / \mathrm{M}$ & $\mathrm{IH}, \mathrm{IVH}$ & $\begin{array}{l}\text { Bilateral AEA of the } \\
\text { OA }\end{array}$ & $\begin{array}{l}\text { Frontal vein to the } \\
\text { SSS }\end{array}$ & IV & $\begin{array}{l}\text { TAE: via the AEA of } \\
\text { the OA with Onyx. }\end{array}$ & Complete & No & Good \\
\hline 30 & $\begin{array}{l}\mathrm{Li} \text { et } \\
\text { al./2014[30] }\end{array}$ & $\begin{array}{l}\text { NM } \\
\text { (range: } \\
\text { 38-68) }\end{array}$ & $\mathrm{IH}$ & $\begin{array}{l}\text { Unilateral AEA of the } \\
\text { OA, ethmoidal } \\
\text { branches of the IMA } \\
\text { and MMA }\end{array}$ & $\begin{array}{l}\text { Frontal vein to the } \\
\text { SSS }\end{array}$ & III or IV & $\begin{array}{l}\text { TAE: via AEA of the } \\
\text { OA with Onyx. }\end{array}$ & Incomplete & No & Good \\
\hline 31 & $\begin{array}{l}\text { Li et } \\
\text { al./2014[30] }\end{array}$ & $\begin{array}{l}\text { NM } \\
\text { (range: } \\
38-68 \text { ) }\end{array}$ & $\mathrm{IH}$ & $\begin{array}{l}\text { Unilateral AEA of the } \\
\text { OA and ethmoidal } \\
\text { branch of the IMA; } \\
\text { Bilateral pial branches } \\
\text { of the ACAs }\end{array}$ & $\begin{array}{l}\text { Frontal vein to the } \\
\text { SSS }\end{array}$ & III or IV & $\begin{array}{l}\text { TAE: via the MMA } \\
\text { and pial branches of } \\
\text { the ACAs with Onyx. }\end{array}$ & Complete & $\begin{array}{l}\text { Microcatheter } \\
\text { entrapment }\end{array}$ & Good \\
\hline 32 & $\begin{array}{l}\text { Li et } \\
\text { al./2014[30] }\end{array}$ & $\begin{array}{l}\text { NM } \\
\text { (range: } \\
\text { 38-68) }\end{array}$ & IH, IVH & $\begin{array}{l}\text { Bilateral AEA of the } \\
\text { OA }\end{array}$ & $\begin{array}{l}\text { Frontal vein to the } \\
\text { SSS; inferior frontal } \\
\text { vein into the } \\
\text { sylvian veins }\end{array}$ & IV & $\begin{array}{l}\text { TAE: via both AEAs } \\
\text { of the OAs with } \\
\text { Onyx. }\end{array}$ & Complete & No & Good \\
\hline 33 & $\begin{array}{l}\text { Li et } \\
\text { al./2014[30] }\end{array}$ & $\begin{array}{l}\text { NM } \\
\text { (range: } \\
38-68 \text { ) }\end{array}$ & $\mathrm{IH}$ & $\begin{array}{l}\text { Bilateral AEA of the } \\
\text { OA, unilateral } \\
\text { ethmoidal branch of } \\
\text { the IMA }\end{array}$ & $\begin{array}{l}\text { Frontal vein to the } \\
\text { SSS; Ophthalmic } \\
\text { vein }\end{array}$ & III or IV & $\begin{array}{l}\text { TAE: via both AEAs } \\
\text { of the OAs with } \\
\text { Onyx. }\end{array}$ & Complete & No & Good \\
\hline 34 & $\begin{array}{l}\mathrm{Li} \text { et } \\
\text { al./2014[30] }\end{array}$ & $\begin{array}{l}\text { NM } \\
\text { (range: } \\
\text { 38-68) }\end{array}$ & Asymptomatic & $\begin{array}{l}\text { Bilateral AEA of the } \\
\text { OA }\end{array}$ & $\begin{array}{l}\text { Frontal vein to the } \\
\text { SSS; Basal vein of } \\
\text { Rosenthal }\end{array}$ & IV & $\begin{array}{l}\text { TAE: via the AEA of } \\
\text { the OA with Onyx. }\end{array}$ & Complete & No & Good \\
\hline 35 & $\begin{array}{l}\text { Li et } \\
\text { al./2014[30] }\end{array}$ & $\begin{array}{l}\text { NM } \\
\text { (range: } \\
\text { 38-68) }\end{array}$ & $\mathrm{IH}$ & $\begin{array}{l}\text { Bilateral AEA of the } \\
\text { OA }\end{array}$ & $\begin{array}{l}\text { Inferior frontal } \\
\text { cortical vein into } \\
\text { the sylvian veins }\end{array}$ & III or IV & $\begin{array}{l}\text { TAE: via the AEA of } \\
\text { the OA with Onyx. }\end{array}$ & Complete & No & Good \\
\hline 36 & $\begin{array}{l}\text { Spiotta et } \\
\text { al./2014[31] }\end{array}$ & $41 / \mathrm{M}$ & $\begin{array}{l}\text { Headache and } \\
\text { blurred vision }\end{array}$ & $\begin{array}{l}\text { Bilateral AEA of the } \\
\text { OA }\end{array}$ & $\begin{array}{l}\text { Frontal vein to the } \\
\text { SSS }\end{array}$ & III & $\begin{array}{l}\text { TAE: via the AEA of } \\
\text { the OA with Onyx. } \\
\text { TVE: Trans-SSS } \\
\text { approach with Onyx }\end{array}$ & Complete & No & Good \\
\hline 37 & $\begin{array}{l}\text { Spiotta et } \\
\text { al./2014[31] }\end{array}$ & $72 / \mathrm{M}$ & Headache & $\begin{array}{l}\text { Bilateral AEA of the } \\
\text { OA }\end{array}$ & $\begin{array}{l}\text { Frontal vein to the } \\
\text { SSS }\end{array}$ & III & $\begin{array}{l}\text { TVE: Trans-SSS } \\
\text { approach with Onyx }\end{array}$ & Complete & No & Good \\
\hline 38 & $\begin{array}{l}\text { Spiotta et } \\
\text { al./2014[31] }\end{array}$ & $55 / F$ & Headache & $\begin{array}{l}\text { Bilateral AEA of the } \\
\text { OA }\end{array}$ & $\begin{array}{l}\text { Frontal vein to the } \\
\text { SSS, Basal vein of } \\
\text { Rosenthal }\end{array}$ & III & $\begin{array}{l}\text { TVE: Trans-SSS } \\
\text { approach with Onyx }\end{array}$ & Complete & No & Good \\
\hline 39 & $\begin{array}{l}\text { Albuquerque } \\
\text { et al./2014[32] }\end{array}$ & NM & Asymptomatic & $\begin{array}{l}\text { Unilateral AEA of the } \\
\text { OA }\end{array}$ & $\begin{array}{l}\text { Frontal vein to the } \\
\text { SSS }\end{array}$ & III & $\begin{array}{l}\text { TVE: Trans-SSS } \\
\text { approach with coils. }\end{array}$ & Complete & No & Good \\
\hline 40 & $\begin{array}{l}\text { Deng et } \\
\text { al./2014[14] }\end{array}$ & NM & Headache & $\begin{array}{l}\text { Bilateral AEA of the } \\
\text { OA, Unilateral MMA } \\
\text { and ethmoidal } \\
\text { branches of the IMA }\end{array}$ & $\begin{array}{l}\text { Frontal vein to the } \\
\text { SSS, Basal vein of } \\
\text { Rosenthal }\end{array}$ & IV & $\begin{array}{l}\text { TAE: via the MMA to } \\
\text { embolize the DAVF } \\
\text { with Onyx. }\end{array}$ & Complete & No & IM \\
\hline 41 & $\begin{array}{l}\text { Deng et } \\
\text { al./2014[14] }\end{array}$ & NM & $\mathrm{SAH}$ & $\begin{array}{l}\text { Bilateral AEA of the } \\
\text { OA, Unilateral MMA }\end{array}$ & $\begin{array}{l}\text { Frontal vein to the } \\
\text { SSS }\end{array}$ & IV & $\begin{array}{l}\text { TAE: via the MMA to } \\
\text { embolize the DAVF } \\
\text { with Onyx. }\end{array}$ & Complete & No & Good \\
\hline 42 & $\begin{array}{l}\text { Inoue et } \\
\text { al./2014[33] }\end{array}$ & $58 / \mathrm{M}$ & $\begin{array}{l}\text { Exophthalmos, } \\
\text { chemosis and } \\
\text { diplopia }\end{array}$ & $\begin{array}{l}\text { Bilateral AEA of the } \\
\text { OA }\end{array}$ & $\begin{array}{l}\text { Superior and } \\
\text { inferior } \\
\text { ophthalmic veins }\end{array}$ & III & $\begin{array}{l}\text { TAE: via both AEAs } \\
\text { of the OAs with } \\
\text { NBCA }\end{array}$ & Complete & No & Good \\
\hline 43 & $\begin{array}{l}\text { Cannizzaro et } \\
\text { al./2018[34] }\end{array}$ & $80 / \mathrm{M}$ & Headache & $\begin{array}{l}\text { Unilateral AEA of the } \\
\text { OA, ethmoidal } \\
\text { branches of the IMA } \\
\text { and MMA }\end{array}$ & $\begin{array}{l}\text { Frontal vein to the } \\
\text { SSS }\end{array}$ & IV & $\begin{array}{l}\text { TAE: via the MMA to } \\
\text { embolize the DAVF } \\
\text { with Onyx. }\end{array}$ & Complete & No & Good \\
\hline 44 & $\begin{array}{l}\text { Limbucci et } \\
\text { al./2018[35] }\end{array}$ & $59 / F$ & Headache & $\begin{array}{l}\text { Bilateral AEA of the } \\
\text { OA }\end{array}$ & $\begin{array}{l}\text { Frontal vein to the } \\
\text { SSS }\end{array}$ & III & $\begin{array}{l}\text { TVE: Trans-SSS } \\
\text { approach with coils. }\end{array}$ & Complete & No & Good \\
\hline 45 & $\begin{array}{l}\text { Limbucci et } \\
\text { al./2018[35] }\end{array}$ & $63 / F$ & Asymptomatic & $\begin{array}{l}\text { Bilateral AEA of the } \\
\text { OA }\end{array}$ & $\begin{array}{l}\text { Frontal vein to the } \\
\text { SSS }\end{array}$ & III & $\begin{array}{l}\text { TVE: Trans-SSS } \\
\text { approach with Onyx }\end{array}$ & Complete & No & Good \\
\hline
\end{tabular}




\begin{tabular}{|c|c|c|c|c|c|c|c|c|c|c|}
\hline 46 & $\begin{array}{l}\text { Limbucci et } \\
\text { al./2018[35] }\end{array}$ & $50 / \mathrm{M}$ & Asymptomatic & $\begin{array}{l}\text { Bilateral AEA of the } \\
\text { OA }\end{array}$ & $\begin{array}{l}\text { Frontal vein to the } \\
\text { SSS }\end{array}$ & III & $\begin{array}{l}\text { TVE: Trans-SSS } \\
\text { approach with Onyx }\end{array}$ & Complete & No & Good \\
\hline 47 & $\begin{array}{l}\text { Limbucci et } \\
\text { al./2018[35] }\end{array}$ & $70 / \mathrm{M}$ & $\mathrm{IH}$ & $\begin{array}{l}\text { Bilateral AEA of the } \\
\text { OA, ethmoidal } \\
\text { branches of the IMA }\end{array}$ & $\begin{array}{l}\text { Basal vein of } \\
\text { Rosenthal }\end{array}$ & IV & $\begin{array}{l}\text { TVE: Trans-Basal } \\
\text { vein of Rosenthal } \\
\text { approach with Onyx }\end{array}$ & Complete & No & Good \\
\hline 48 & $\begin{array}{l}\text { Sirakov et } \\
\text { al./2018[36] }\end{array}$ & $40 / \mathrm{M}$ & $\mathrm{SDH}$ & $\begin{array}{l}\text { Bilateral AEA of the } \\
\text { OA }\end{array}$ & $\begin{array}{l}\text { Frontal vein to the } \\
\text { SSS }\end{array}$ & IV & $\begin{array}{l}\text { TAE: via the AEA of } \\
\text { the OA with Onyx. }\end{array}$ & Complete & No & Good \\
\hline
\end{tabular}

Abbreviations: EVT: endovascular treatment; ACF: anterior cranial fossa; DAVF: dural arteriovenous fistula; M: male; IH: Intracerebral hematoma; AEA: anterior ethmoidal artery; OA: ophthalmic artery; SSS: superior sagittal sinus; TAE: transarterial embolization; NBCA: N-butyl-2-cyanoacrylate; SAH: subarachnoid hemorrhage; IMA: Internal maxillary artery; TVE: transvenous embolization; MMA: middle meningeal artery; ACA: anterior cerebral artery; MCA: middle cerebral artery; PEA: posterior ethmoidal artery; F: female; IM: improved; SDH: subdural hematoma; IVH: intraventricular hemorrhage; NM: not mentioned

Table 2: General and angiographic data in ACF DAVF series

\begin{tabular}{|c|c|c|c|c|c|c|c|}
\hline No. & Author/Year & Cases & $\begin{array}{l}\text { Mean Age } \\
\text { (years) }\end{array}$ & $\begin{array}{l}\text { Male } \\
\text { Sex }\end{array}$ & $\begin{array}{l}\text { Hemorrhagic } \\
\text { presentation }\end{array}$ & Arterial feeders & Venous drainage \\
\hline 1 & $\begin{array}{l}\text { Başkaya et } \\
\text { al./1994[6] }\end{array}$ & $\begin{array}{l}50 \\
\text { cases }\end{array}$ & 56 & $81 \%$ & $77 \%$ & AEA of the OA: $100 \%$. & Frontal vein into the SSS: $75 \%$. \\
\hline 2 & $\begin{array}{l}\text { Lawton et } \\
\text { al./1999[38] }\end{array}$ & $\begin{array}{l}16 \\
\text { cases }\end{array}$ & 62 & $68 \%$ & $50 \%$ & $\begin{array}{l}\text { AEA of the OA: } 100 \% \text { ( } 50 \% \text { were } \\
\text { bilateral). } \\
\text { Ethmoidal branch of the IMA: } 31 \% \text {. }\end{array}$ & $\begin{array}{l}\text { Frontal vein into the SSS: } 62.5 \% \text {. } \\
\text { Cavernous sinus: } 44.8 \% \text {. } \\
\text { Basal vein of Rosenthal: } 2.5 \% \text {. } \\
\text { Labbé vein: } 2.5 \% \text {. } \\
\text { Venous ectasia: } 69 \% \text {. }\end{array}$ \\
\hline 3 & Agid et al./2009[9] & $\begin{array}{l}24 \\
\text { cases }\end{array}$ & 57 & $92 \%$ & $46 \%$ & $\begin{array}{l}\text { AEA of the OA: } 100 \% \text { (all were bilateral). } \\
\text { Ethmoidal branch of the IMA and MMA: } \\
62 \% \text {. }\end{array}$ & $\begin{array}{l}\text { Frontal vein into the SSS: } 75 \% \text {. } \\
\text { Superficial sylvian veins: } 21 \% \text {. } \\
\text { Basal vein of Rosenthal: } 4 \% . \\
\text { Venous ectasia: } 46 \% \text {. }\end{array}$ \\
\hline 4 & Li et al./2013[12] & $\begin{array}{l}11 \\
\text { cases }\end{array}$ & 50 & $91 \%$ & $82 \%$ & $\begin{array}{l}\text { AEA of the OA: } 100 \% \text { (all bilateral). } \\
\text { Ethmoidal branch of the IMA: } 36 \% \text {. } \\
\text { MMA: } 27 \% \text {. } \\
\text { Pial branch of the ACA: } 18 \% \text {. } \\
\text { Branches of the facial artery: } 18 \% \text {. } \\
\text { Flow-related aneurysms: } 18 \% \text {. }\end{array}$ & $\begin{array}{l}\text { Frontal vein into the SSS: } 100 \% \text {. } \\
\text { Venous ectasia: } 73 \% \text {. } \\
\text { Cavernous sinus and Basal vein of } \\
\text { Rosenthal: } 18 \% \text {. }\end{array}$ \\
\hline 5 & Gross et al./2016[4] & $\begin{array}{l}27 \\
\text { cases }\end{array}$ & 62 & $67 \%$ & $37 \%$ & $\begin{array}{l}\text { AEA of the OA: } 93 \% \text { (all bilateral). } \\
\text { Ethmoidal branch of the IMA: } 66 \% \\
\text { (bilateral in } 48 \% \text { ). } \\
\text { MMA: } 22 \% \text {. } \\
\text { Dural branch of ICA: } 7 \% . \\
\text { Pial branch of the ACA: } 7 \% \text {. } \\
\text { Flow-related aneurysms: } 7 \% \text {. }\end{array}$ & $\begin{array}{l}\text { Frontal vein into the SSS: } 70 \% \text {. } \\
\text { Basal vein of Rosenthal: } 19 \% \text {. } \\
\text { Superficial sylvian veins and Trolard or } \\
\text { Labbé veins: } 11 \% \text {. } \\
\text { Venous ectasia: } 59 \% \text {. }\end{array}$ \\
\hline 6 & $\begin{array}{l}\text { Robert et } \\
\text { al./2016[37] }\end{array}$ & $\begin{array}{l}10 \\
\text { cases }\end{array}$ & 59 & $67 \%$ & $20 \%$ & $\begin{array}{l}\text { AEA of the OA: } 100 \% \text { ( } 80 \% \text { were } \\
\text { bilateral). } \\
\text { Ethmoidal branch of the IMA: } 20 \% \text {. } \\
\text { MMA: } 30 \% \text {. }\end{array}$ & $\begin{array}{l}\text { Frontal vein into the SSS: } 60 \% \text {. } \\
\text { Cavernous sinus: } 20 \% \text {. } \\
\text { Superficial sylvian veins: } 20 \% \text {. } \\
\text { Venous ectasia: } 70 \% \text {. }\end{array}$ \\
\hline
\end{tabular}

Abbreviations: ACF: anterior cranial fossa; DAVF: dural arteriovenous fistula; AEA: anterior ethmoidal artery; OA: ophthalmic artery; SSS: superior sagittal sinus; IMA: internal maxillary artery; MMA: Middle meningeal artery; ACA: anterior cerebral artery; ICA internal carotid artery

\section{Discussion}

\section{Angioarchitecture and grade}

In ACF DAVFs, the sources of the main feeding arteries are the AEA of the OA and are primarily bilateral[4, 5, 8, 9, 11, 24, 31, 37]. In the considered ACF DAVF studies (Table 2), the involvement of the AEA of the OA was $93-100 \%$, and $50-100 \%$ of ACF DAVFs had bilateral feeding arteries $[4,6,9,12,37$, 38]. In the identified 48 cases, $97.9 \%$ of patients had feeding arteries from the AEA of the OA, and $83.3 \%$ of patients had bilateral feeding arteries.

The MMA can be involved in ACF DAVFs and, when involved, is typically unilateral [14, 15, 37]. In the considered ACF DAVF studies (Table 2), the rate of MMA involvement was $20-30 \%[4,6,9,12,37,38]$. In the 48 analyzed cases, the overall rate was $20.8 \%$. The ethmoidal branch (sphenopalatine artery) of the internal maxillary artery (IMA) was also involved in ACF DAVFs. In the studies considered in this series (Table 2), the rate of involvement of the ethmoidal branch of the IMA was $20-66 \%[4,6,9,12,37,38]$. In the 48 cases, the overall rate was $33.3 \%[8,11,12,23$, $28,30]$.

In addition, the pial branches of the ACA and MCA, the angular branch of the facial artery and even the persistent primitive olfactory artery can be involved in ACF DAVFs in rare cases $[4,9,12,25,27$, $39,40]$. Flow-related aneurysms can occur in the feeding artery in $18 \%$ of cases [12].

The fistula point of an ACF DAVF is usually located at the level of the cribriform plate in the lateral epidural space, which includes the lamina cribrosa and the orbital roofs. The fistula point of an ACF DAVF is most often single and located on one side of the cribriform plate [11]. Rarely, an ACF DAVF can occur bilaterally [41, 42].

The venous drainage routes of ACF DAVFs include drainage to the frontal veins and then secondarily into the SSS, via the olfactory vein to the cavernous sinus or the basal vein of Rosenthal, or to the sylvian veins and then ultimately into the vein of 
Trolard or Labbé $[8,11,12,15,24,28,38,43,44]$. These venous drainage routes are usually unilateral but can be bilateral in rare cases [40].

Of all such venous drainage routes, the frontal cortical veins to the SSS are the most frequently affected [8, 9, 12]. In the considered ACF DAVF studies (Table 2), the rate of drainage into the SSS was $60-100 \%[4,6,9,12,37,38]$. In the 48 cases, the overall rate was $89.6 \%$.

In addition, Gross et al. reported that in 19\% of all cases, ACF DAVFs had venous drainage that was routed posteriorly into the basal vein of Rosenthal and then into the deep venous circulation, sometimes including the lateral mesencephalic vein $[4,11]$. In the 48 analyzed cases, $16.7 \%$ of patients had drainage via Basal vein of Rosenthal. This drainage pattern could be related to hemorrhages that occur at a position remote from the DAVF site $[10,28,30]$.

Because the ACF contains no dural sinuses, ACF DAVFs always drain via the cortical venous drainage system. In approximately one-half of ACF DAVFs, hemodynamic stress causes fragile draining veins to undergo progressive structural modifications, including dilation and the formation of a venous aneurysm [8-12, 40, 45-49]. Hence, when using the Cognard classification system, ACF DAVFs are often graded as Cognard Type III/IV [10, 12, 24, 37, 50-52]. The 48 cases we considered all had high-grade (III-IV) Cognard classifications.

Cognard et al. noted that intracranial hemorrhage was observed in $10 \%$ of patients with type II, $40 \%$ with type III and $65 \%$ with type IV DAVFs [51]. In the assessed ACF DAVF studies (Table 2 ), the rate of intracranial hemorrhage was $22-82 \%$ [4, $6,9,12,37,38]$. In the 48 cases, the overall rate of intracranial hemorrhage was $58.3 \%$.

\section{Outline of EVT}

The therapeutic goal of EVT is for the embolic agents to penetrate through the transosseous shunt to obliterate the fistula point $[4,12]$. Performing TAE through the OA is considered technically challenging because the surgeon must avoid occluding the central retinal artery (CRA) [17, 30]. TVE can achieve complete obliteration, but the route from the puncture point to the DAVF is long and difficult to navigate, especially when passing the venous varix, and TVE is more time consuming and therefore requires more patience [10].

In ACF DAVFs, EVT should be considered only in patients with favorable angiographic anatomy. However, in appropriate patients, EVT is effective and associated with a high obliteration rate [14]. TAE is the first option in cases with good transarterial access to the fistulous point (e.g., via a large and easily navigable OA with limited proximal vessel tortuosity) that allows distal microcatheterization to be performed in close proximity to the fistulous point and a tolerable degree of reflux $[14,17,30]$. Additionally, due to safety issues, TVE is preferred if the ACF DAVF has an easily navigable draining vein and covers a short cortical distance [10,37].

\section{Transarterial embolization}

When performing TAE for ACF DAVFs, almost all feeding arteries can be used as the TAE path [24, 30]. However, TAE is rarely performed when the feeding arteries are too thin, such as when the ethmoidal branch of the IMA is involved [11, 38]. Currently, TAE is primarily performed via the OA and MMA, although in rare cases, the facial artery can be used [27].

\section{(i) AEA of OA}

In ACF DAVFs, the AEA of the OA is the most frequently reported feeding artery, and in these cases, TAE must be performed via these arteries $[12,53]$. In the 48 studied cases, 36 patients were treated via TAE. Of these 36 patients, $28(77.8 \%$, 28/36) were managed via the AEA of the OA. When using TAE to treat an ACF DAVF via the OA, the CRA must be given sufficient consideration during Onyx injection to reduce the risk of retinal ischemia and acute vision loss. Because the space available for Onyx reflux is limited in these patients, excessive reflux should be strictly controlled $[9,30]$.

The origin of the CRA is at the same level of the ciliary arteries and originates from the second segment of the OA [54]. Therefore, the surgeon should ensure that the ciliary arteries are recognized. Moreover, it is essential that there is no evidence of retinal choroidal blush on superselective angiography before the Onyx injection is performed [30]. Therefore, the optimal position of the microcatheter is as close as possible to the fistula, and the microcatheter should be placed in the third segment of the OA immediately proximal to the origin of the AEA. Finally, when injecting Onyx, the origin of the CRV should also be noted and kept under consideration [37, 55].

\section{(ii) MMA}

In ACF DAVFs, the MMA is usually not the main feeding artery, and its route to the DAVF is very long and occasionally tortuous. For this reason, the MMA is not often used for TAE [14, 15]. However, the MMA is actually an excellent path to take when performing TAE because it is strongly resistant to rupturing when the microcatheter is pulled back. Moreover, this vessel contains sufficient space for Onyx reflux, increasing the forward penetration of the Onyx into vascular networks, including nearby drainage veins or feeders 
$[15,56,57]$. Occasionally, a dual lumen balloon and the pressure-cooker technique can help to increase the penetration of the Onyx [37]. In our summarized 48 cases, 36 were treated via TAE. Of these 36 patients, 6 $(16.7 \%, 6 / 36)$ were managed via the MMA.

However, most ACF DAVFs are primarily supplied by the ethmoidal artery, and in these cases, the OA must be used [12].

\section{Transvenous embolization}

In ACF DAVFs, the main advantage of TVE over TAE is that TVE is not associated with a risk of occluding the CRA because the Onyx is deployed directly into the vein $[4,10]$. In TVE, the trans-SSS approach is widely used. In the 48 cases considered herein, $12(25 \%, 12 / 48)$ patients were treated via TVE, and $11(91.7 \%, 11 / 12)$ were treated with the trans-SSS approach. The TVE approach via deep veins is considered to be dangerous.

However, when TVE is used in ACF DAVFs, venous retrograde catheterization becomes difficult because the transvenous routes are tortuous $[11,58]$. To overcome this difficulty, it is recommended that TVE be performed via a puncture of the internal jugular vein $[10,11]$. In addition, it can be helpful to use a flexible intracranial guiding catheter or an intermediate catheter that is advanced to the ostium of the cortical draining vein $[10,31]$.

When TVE is performed in an ACF DAVF, after the microcatheter tip is positioned in the fistula point, arteriography of the $\mathrm{OA}$ and superselective venography of the microcatheter are necessary to confirm the placement of the microcatheter tip [11, 31]. When performing TVE, Onyx is a good choice because it can penetrate the fistula through the cribriform plate and can pass retrogradely into the tiny transosseous arterial feeders [59]. In the 48 cases we considered, we found that Onyx has become popular in EVT for ACF DAVFs since 2005.

\section{Complications}

In EVT for ACF DAVFs, the overall complication rate is $6.25 \%$ [4]. In the 48 cases considered in this review, the rate of postprocedure complications was $8.3 \%$. Of all complications, CRA ischemia is the most dangerous and damaging complication associated with TAE and is caused by Onyx excessive reflux into the OA [37]. In our paper, $2(4.2 \%, 2 / 47)$ patients experienced excessive Onyx reflux. Thus, when retrograde Onyx approaches the origin of the CRA, low molecular-weight heparin should be postoperatively administered every $12 \mathrm{~h}$ for the first $72 \mathrm{~h}$, and $100 \mathrm{mg}$ aspirin should be administered per day for the first month to prevent ischemic events in the CRA [12].
Microcatheter retention can occur when using an undetachable microcatheter. In addition, while injecting Onyx via a feeding artery in TAE, the Onyx may reflux into the contralateral ethmoidal branches and then into the OA. Therefore, the inappropriate migration of Onyx to the contralateral side must be closely monitored during injection [60].

When performing TVE in a patient with tortuous vein anatomy, vein navigation may cause venous perforation, resulting in intracranial hemorrhage. Alternatively, the microcatheter can become embedded in the veins. Hence, excessively tortuous vein anatomy is a contraindication for TVE [30]. Rarely, if the EVT disturbs the drainage of the deep vein system, congestion in the BVR is likely to result in transient thalamic and brainstem edema.

\section{Prognosis}

After appropriate patients are selected, EVT, including TAE and TVE, achieve good therapeutic outcomes [10, 12, 15, 28, 30]. From a statistical standpoint, TAE has an occlusion rate ranging from $12.5 \%$ to $63.6 \%$ in ACF DAVFs [4, 9], whereas TVE has achieved a complete occlusion rate of $63.3-91 \%$ in a larger series [8]. Completely occluding the ACF DAVF is associated with good outcomes. In the 48 cases considered herein, $91.7 \%$ of patients experienced complete angiographic cure, and $93.8 \%$ of patients had a good outcome.

\section{Summary}

The fistula point of an ACF DAVF is usually located at the level of the cribriform plate, and the AEA of the OA was the most commonly observed feeding artery. The frontal cortical veins to the SSS are the most frequently involved. Because of their cortical vein drainage pattern, ACF DAVFs often have a malignant natural history with high-grade Cognard classifications (III-IV). EVT, including TAE and TVE, is currently considered an effective therapeutic option in ACF DAVFs. The therapeutic goal of EVT is for the embolic agents to penetrate through the transosseous shunt to obliterate the fistula point.

When performing TAE through the AEA of the $\mathrm{OA}$, it is important to ensure that the CRA is not occluded. TVE can also achieve complete obliteration, but the path from the puncture point to the DAVF is longer and difficult to navigate, meaning that TVE is more time consuming and requires more patience. EVT is associated with both technique- and treatment-related complications. However, although complications may occur, AVF DAVFs have an acceptable prognosis when the patients are appropriately selected. 


\section{Limitations}

ACF DAVFs are rare intracranial lesions, most of which are sporadically presented as case reports. As a result of the small sample size in this review, the statistical analysis is inappropriate. Because of the selection criteria in this study, cases without adequate description of the patients' medical histories were excluded. Cases mixed in with larger case series with DAVFs of other intracranial locations were also occasionally omitted due to the difficulty of data extraction. Furthermore, only articles written in English were included in this study. Hence, the findings of this review may not reflect actual circumstances in the clinic, and readers should interpret the presented results with the appropriate level of caution.

\section{Competing Interests}

The authors have declared that no competing interest exists.

\section{References}

1. Guo Y, Yu J, Zhao Y, Yu J. Progress in research on intracranial multiple dural arteriovenous fistulas. Biomed Rep. 2018; 8: 17-25.

2. $\mathrm{Yu} \mathrm{J}, \mathrm{Lv} \mathrm{X}, \mathrm{Li} \mathrm{Y}, \mathrm{Wu} \mathrm{Z}$. Therapeutic progress in pediatric intracranial dural arteriovenous shunts: A review. Interv Neuroradiol. 2016; 22: 548-56.

3. Ishikawa T, Houkin K, Tokuda K, Kawaguchi S, Kashiwaba T. Development of anterior cranial fossa dural arteriovenous malformation following head trauma. Case report. J Neurosurg. 1997; 86: 291-3.

4. Gross BA, Moon K, Kalani MY, Albuquerque FC, McDougall CG, Nakaji P, et al. Clinical and Anatomic Insights From a Series of Ethmoidal Dural Arteriovenous Fistulas at Barrow Neurological Institute. World Neurosurg. 2016; 93: 94-9.

5. Hattori T, Kobayashi H, Inoue S, Sakai N. Angiographically occult dural arteriovenous malformation in the anterior cranial fossa--case report. Neurol Med Chir (Tokyo). 1999; 39: 291-3.

6. Baskaya MK, Suzuki Y, Seki Y, Negoro M, Ahmed M, Sugita K. Dural arteriovenous malformations in the anterior cranial fossa. Acta Neurochir (Wien). 1994; 129: 146-51.

7. Tsai LK, Liu HM, Jeng JS. Diagnosis and management of intracranial dural arteriovenous fistulas. Expert Rev Neurother. 2016; 16: 307-18

8. Meneghelli P, Pasqualin A, Lanterna LA, Bernucci C, Spinelli R, Dorelli G, et al. Surgical treatment of anterior cranial fossa dural arterio-venous fistulas (DAVFs): a two-centre experience. Acta Neurochir (Wien). 2017; 159: 823-30.

9. Agid R, Terbrugge K, Rodesch G, Andersson T, Soderman M. Management strategies for anterior cranial fossa (ethmoidal) dural arteriovenous fistulas with an emphasis on endovascular treatment. J Neurosurg. 2009; 110: 79-84

10. Limbucci N, Leone G, Nappini S, Rosi A, Renieri L, Consoli A, et al. Transvenous Embolization of Ethmoidal Dural Arteriovenous Fistulas: Case Series and Review of the Literature. World Neurosurg. 2017.

11. Defreyne L, Vanlangenhove P, Vandekerckhove T, Deschrijver I, Sieben G, Klaes R, et al. Transvenous embolization of a dural arteriovenous fistula of the anterior cranial fossa: preliminary results. AJNR Am J Neuroradiol. 2000; 21: $761-5$

12. Li Q, Fang YB, Huang QH, Zhang Q, Hong B, Zhao WY, et al. Transarterial embolization of dural arteriovenous fistulas of the anterior cranial fossa with Onyx. J Clin Neurosci. 2013: 20: 287-91.

13. Kortman HG, Bloemsma G, Boukrab I, Peluso JP, Sluzewski M, van der Pol B, et al. Treatment of cranial dural arteriovenous fistulas with exclusive cortical venous drainage: A single-center cohort of 35 patients. Interv Neuroradiol. 2017; 23: 661-5.

14. Deng JP, Li J, Zhang T, Yu J, Zhao ZW, Gao GD. Embolization of dural arteriovenous fistula of the anterior cranial fossa through the middle meningeal artery with Onyx. Clin Neurol Neurosurg. 2014; 117: 1-5.

15. Cannizzaro D, Peschillo S, Cenzato M, Pero G, Resta MC, Guidetti G, et al. Endovascular and surgical approaches of ethmoidal dural fistulas: a multicenter experience and a literature review. Neurosurg Rev. 2016.

16. Liberati A, Altman DG, Tetzlaff J, Mulrow C, Gotzsche PC, Ioannidis JP, et al. The PRISMA statement for reporting systematic reviews and meta-analyses of studies that evaluate healthcare interventions: explanation and elaboration. BMJ. 2009; 339: b2700.
17. Matsumaru Y, Alvarez H, Rodesch G, Lasjaunias PL. Embolisation of branches of the ophthalmic artery. Interv Neuroradiol. 1997; 3: 239-45.

18. Abrahams JM, Bagley LJ, Flamm ES, Hurst RW, Sinson GP. Alternative management considerations for ethmoidal dural arteriovenous fistulas. Surg Neurol. 2002; 58: 410-6; discussion 6

19. Flynn TH, McSweeney S, O'Connor G, Kaar G, Ryder DQ. Dural AVM supplied by the ophthalmic artery. Br J Neurosurg. 2007; 21: 414-6.

20. Xianli L, Youxiang L, Aihua L, Ming L, Zhongxue W. Transarterial embolization of dural arteriovenous fistulas of the anterior cranial fossa using onyx-18. A case report. Neuroradiol J. 2007; 20: 348-54.

21. Katsaridis V, Papagiannaki C, Violaris C. Endovascular treatment of a bilateral ophthalmic-ethmoidal artery dural arteriovenous fistula. J Neuroophthalmol. 2007; 27: 281-4.

22. Lv X, Jiang C, Li Y, Yang X, Wu Z. Percutaneous Transvenous Embolization of Intracranial Dural Arteriovenous Fistulas with Detachable Coils and/or in Combination with Onyx. Interv Neuroradiol. 2008; 14: 415-27.

23. $\mathrm{Lv} \mathrm{X}, \mathrm{Li} \mathrm{Y}, \mathrm{Wu} \mathrm{Z}$. Endovascular treatment of anterior cranial fossa dural arteriovenous fistula. Neuroradiology. 2008; 50: 433-7.

24. Tahon F, Salkine F, Amsalem Y, Aguettaz P, Lamy B, Turjman F. Dural arteriovenous fistula of the anterior fossa treated with the Onyx liquid embolic system and the Sonic microcatheter. Neuroradiology. 2008; 50: 429-32.

25. Tsutsumi S, Shimizu Y, Nonaka Y, Abe Y, Yasumoto Y, Ito M, et al. Arteriovenous fistula arising from the persistent primitive olfactory artery with dual supply from the bilateral anterior ethmoidal arteries. Neurol Med Chir (Tokyo). 2009; 49: 407-9.

26. Guedin P, Gaillard S, Boulin A, Condette-Auliac S, Bourdain F, Guieu S, et al. Therapeutic management of intracranial dural arteriovenous shunts with leptomeningeal venous drainage: report of 53 consecutive patients with emphasis on transarterial embolization with acrylic glue. J Neurosurg. 2010; 112: $603-10$

27. Ishihara $\mathrm{H}$, Ishihara $\mathrm{S}$, Neki $\mathrm{H}$, Okawara $\mathrm{M}$, Kanazawa $\mathrm{R}$, Kohyama $\mathrm{S}$, et al. Dural arteriovenous fistula of the anterior cranial fossa with carotid artery stenosis treated by simultaneous transarterial embolization and carotid artery stenting. Neurol Med Chir (Tokyo). 2010; 50: 995-7.

28. Mack WJ, Gonzalez NR, Jahan R, Vinuela F. Endovascular management of anterior cranial fossa dural arteriovenous malformations. A technical report and anatomical discussion. Interv Neuroradiol. 2011; 17: 93-103.

29. Zhao WY, Krings T, Yang PF, Liu JM, Xu Y, Li O et al. Balloon-assisted superselective microcatheterization for transarterial treatment of cranial dural arteriovenous fistulas: technique and results. Neurosurgery. 2012; 71: ons269-73; discussion ons73.

30. Li C, Wu Z, Yang X, Li Y, Jiang C, He H. Transarterial treatment with Onyx of Cognard type IV anterior cranial fossa dural arteriovenous fistulas. J Neurointerv Surg. 2014; 6: 115-20.

31. Spiotta AM, Hawk H, Kellogg RT, Turner RD, Chaudry MI, Turk AS. Transfemoral venous approach for Onyx embolization of anterior fossa dural arteriovenous fistulae. J Neurointerv Surg. 2014; 6: 195-9.

32. Albuquerque FC, Ducruet AF, Crowley RW, Bristol RE, Ahmed A, McDougall CG. Transvenous to arterial Onyx embolization. J Neurointerv Surg. 2014; 6: $281-5$

33. Inoue A, Tagawa M, Kumon $\mathrm{Y}$, Watanabe $\mathrm{H}$, Shoda D, Sugiu $\mathrm{K}$, et al. Ethmoidal dural arteriovenous fistula with unusual drainage route treated by transarterial embolization. J Neurointerv Surg. 2015; 7: e15.

34. Cannizzaro D, Peschillo S, Cenzato M, Pero G, Resta MC, Guidetti G, et al. Endovascular and surgical approaches of ethmoidal dural fistulas: a multicenter experience and a literature review. Neurosurg Rev. 2018; 41: 391-8.

35. Limbucci N, Leone G, Nappini S, Rosi A, Renieri L, Consoli A, et al. Transvenous Embolization of Ethmoidal Dural Arteriovenous Fistulas: Case Series and Review of the Literature. World Neurosurg. 2018; 110: e786-e93.

36. Sirakov S, Sirakov A, Hristov H, Ninov K. Successful endovascular treatment of ruptured bilateral ophthalmic frontal dural arteriovenous fistula. Radiol Case Rep. 2018; 13: 1036-41.

37. Robert $\mathrm{T}$, Blanc $\mathrm{R}$, Smajda S, Ciccio G, Redjem H, Bartolini B, et al. Endovascular treatment of cribriform plate dural arteriovenous fistulas: technical difficulties and complications avoidance. J Neurointerv Surg. 2016; 8: 954-8.

38. Lawton MT, Chun J, Wilson CB, Halbach VV. Ethmoidal dural arteriovenous fistulae: an assessment of surgical and endovascular management. Neurosurgery. 1999; 45: 805-10; discussion 10-1.

39. Ros de San Pedro J, Perez CJ, Parra JZ, Lopez-Guerrero AL, Sanchez JF. Bilateral ethmoidal dural arteriovenous fistula: unexpected surgical diagnosis. Clin Neurol Neurosurg. 2010; 112: 903-8.

40. Kohama M, Nishimura S, Mino M, Hori E, Yonezawa S, Kaimori M, et al Anterior cranial fossa dural arteriovenous fistula with bilateral cortical drainers--case report. Neurol Med Chir (Tokyo). 2010; 50: 217-20.

41. Deshmukh VR, Chang S, Albuquerque FC, McDougall CG, Spetzler RF. Bilateral ethmoidal dural arteriovenous fistulae: a previously unreported entity: case report. Neurosurgery. 2005; 57: E809.

42. Yurekli VA, Orhan G, Gurkas E, Senol N. Bilateral ophthalmic-ethmoidal dural arteriovenous fistula presenting with intracranial hemorrhage: a rare entity. Neurol Sci. 2013; 34: 1851-3.

43. Kiyosue $\mathrm{H}$, Hori $\mathrm{Y}$, Okahara $\mathrm{M}$, Tanoue $\mathrm{S}$, Sagara $\mathrm{Y}$, Matsumoto $\mathrm{S}$, et al Treatment of intracranial dural arteriovenous fistulas: current strategies based on location and hemodynamics, and alternative techniques of transcatheter embolization. Radiographics. 2004; 24: 1637-53. 
44. Tanei T, Fukui K, Wakabayashi K, Mitsui Y, Inoue N, Watanabe M. Dural arteriovenous fistula in the anterior cranial fossa: four case reports. Neurol Med Chir (Tokyo). 2008; 48: 560-3.

45. Ding D, Starke RM, Crowley RW, Liu KC. Interhemispheric approach for endoscopic ligation of an anterior cranial fossa dural arteriovenous fistula. J Clin Neurosci. 2015; 22: 1969-72.

46. Sato K, Shimizu T, Fukuhara T, Namba Y. Ruptured anterior communicating artery aneurysm associated with anterior cranial fossa dural arteriovenous fistula--case report. Neurol Med Chir (Tokyo). 2011; 51: 40-4.

47. Chen Z, Tang W, Liu Z, Li F, Feng H, Zhu G. A dural arteriovenous fistula of the anterior cranial fossa angiographically mimicking an anterior ethmoidal artery aneurysm. J Neuroimaging. 2010; 20: 382-5.

48. Hashiguchi A, Mimata C, Ichimura H, Morioka M, Kuratsu J. Venous aneurysm development associated with a dural arteriovenous fistula of the anterior cranial fossa with devastating hemorrhage--case report. Neurol Med Chir (Tokyo). 2007; 47: 70-3.

49. Ogawa T, Okudera T, Miyauchi T, Inugami A, Uemura K, Yasui N. Anterior cranial fossa dural arteriovenous fistula with a varix mimicking an anterior communicating artery aneurysm. Neuroradiology. 1996; 38: 252-3.

50. Gomez J, Amin AG, Gregg L, Gailloud P. Classification schemes of cranial dural arteriovenous fistulas. Neurosurg Clin N Am. 2012 23. 55-62.

51. Cognard C, Gobin YP, Pierot L, Bailly AL, Houdart E, Casasco A, et al. Cerebral dural arteriovenous fistulas: clinical and angiographic correlation with a revised classification of venous drainage. Radiology. 1995; 194: 671-80.

52. Borden JA, Wu JK, Shucart WA. A proposed classification for spinal and cranial dural arteriovenous fistulous malformations and implications for treatment. J Neurosurg. 1995; 82: 166-79.

53. Gliemroth J, Nowak G, Arnold H. Dural arteriovenous malformation in the anterior cranial fossa. Clin Neurol Neurosurg. 1999; 101: 37-43.

54. Tsutsumi S, Rhoton AL, Jr. Microsurgical anatomy of the central retinal artery. Neurosurgery. 2006; 59: 870-8; discussion 8-9.

55. Alvarez H, Rodesch G, Garcia-Monaco R, Lasjaunias P. Embolisation of the ophthalmic artery branches distal to its visual supply. Surg Radiol Anat. 1990; 12: 293-7.

56. Griessenauer CJ, He L, Salem M, Chua MH, Ogilvy CS, Thomas AJ. Middle meningeal artery: Gateway for effective transarterial Onyx embolization of dural arteriovenous fistulas. Clin Anat. 2016; 29: 718-28.

57. Yu J, Guo Y, Xu B, Xu K. Clinical importance of the middle meningeal artery: A review of the literature. Int J Med Sci. 2016; 13: 790-9.

58. Matsuzaki J, Kono K, Umesaki A, Kashimura Y, Matsumoto H, Terada T. Transvenous Embolization by Direct Puncture of the Superior Sagittal Sinus Using Indocyanine Green(ICG)Videoangiography for Treatment of Dural Arteriovenous Fistula of the Transverse-Sigmoid Sinus:A Case Report]. No Shinkei Geka. 2017; 45: 591-8.

59. Mendes GA, Caire F, Saleme S, Ponomarjova S, Mounayer C. Retrograde leptomeningeal venous approach for dural arteriovenous fistulas at foramen magnum. Interv Neuroradiol. 2015; 21: 244-8.

60. Jamous MA, Satoh $\mathrm{K}$, Satomi J, Matsubara S, Nakajima N, Uno M, et al. Detection of enlarged cortical vein by magnetic resonance imaging contributes to early diagnosis and better outcome for patients with anterior cranial fossa dural arteriovenous fistula. Neurol Med Chir (Tokyo). 2004; 44: 516-20; discussion 20-1. 